\title{
Influence of Early Nutritional Components on the Development of Murine Autoimmune Diabetes
}

\author{
Daniela B. Mueller ${ }^{a}$ Kerstin Koczwara ${ }^{a}$ Andreas S. Mueller ${ }^{c, d}$ Josef Pallauf ${ }^{c}$ \\ Anette-G. Ziegler ${ }^{a}$ b $\quad$ Ezio Bonifacio ${ }^{e}$ \\ ${ }^{a}$ Institut für Diabetesforschung der Forschergruppe Diabetes e.V. am Helmholtz Zentrum München and ${ }^{b}$ Klinik für \\ Endokrinologie, Diabetologie und Suchtmedizin, Klinikum Schwabing, Städt. Klinikum München GmbH, München, \\ 'Institute of Animal Nutrition and Nutritional Physiology, University Giessen, Giessen, ${ }^{d}$ Institute of Agricultural

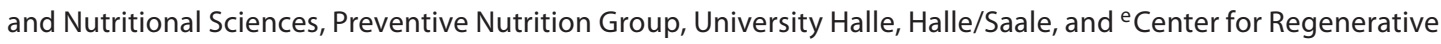 \\ Therapies Dresden, Dresden University of Technology, Dresden, Germany
}

\section{Key Words}

Type 1 diabetes $\cdot$ Autoimmunity $\cdot$ NOD mice $\cdot$ Diet $\cdot$

Prevention · Gluten · Casein

\begin{abstract}
Background/Aims: Infant diet is suggested to modify autoimmune diabetes risk. The aim of this study was to determine whether infant food components affect diabetes development in the nonobese autoimmune diabetes (NOD) mouse. Methods: A basal low-diabetogenic diet was identified by feeding litter-matched female NOD mice standardized diets with and without casein and wheat proteins after weaning. In subsequent trials, basal diet with supplements of wheat $(5,10$ and $30 \%)$, gluten, wheat globulin/albumin, corn $(5 \%)$, potato $(5 \%)$, apple $(5 \%)$ or carrot $(5 \%)$ was fed to litter-matched female NOD mice after weaning. Mice were followed for diabetes development and insulin autoantibodies. Results: A casein- and wheat-free diet was associated with the lowest rate of diabetes development ( $37 \%$ by age 25 weeks). Increased diabetes rates were observed when the basal diet was supplemented with $5 \%$ wheat (71\% by age 25 weeks; $p=0.023$ ) and $5 \%$ corn $(57 \%$ by age 25 weeks; $p=$
\end{abstract}

\section{KARGER}

Fax +4161306 1234 E-Mail karger@karger.ch www.karger.com
(C) 2009 S. Karger AG, Basel

0250-6807/09/0543-0208\$26.00/0

Accessible online at:

www.karger.com/anm
0.05). Increasing wheat concentrations returned diabetes development to that in basal diet-fed mice. Other food supplements had no or minimal effects on diabetes development. Conclusions: Early supplementation of a basal lowdiabetogenic diet with low concentrations of the cereals wheat or corn is associated with a moderate increase in the rate of diabetes. Removal of cereals, however, does not abrogate diabetes development in NOD mice.

Copyright $\odot 2009$ S. Karger AG, Basel

\section{Introduction}

Type 1 diabetes is a T cell-mediated autoimmune disease leading to the destruction of insulin-producing $\beta$ cells in the pancreatic islets of Langerhans. Genetic risk factors predispose and environmental factors modify the risk of developing type 1 diabetes [1]. There are several suggestions that antigen exposure in the gut and through diet may modify the risk of type 1 diabetes [2]. A gut mucosal site of immunization is feasible, since it was shown that there is preferential trafficking of immune cells and antigens from the gastrointestinal tract to the pancreatic

Dr. Kerstin Koczwara

Institut für Diabetesforschung am Helmholtz Zentrum München

Ingolstädter Landstrasse 1, DE-85764 Neuherberg (Germany)

Tel. +49 89318739 06, Fax +49893081733

E-Mail Kerstin.Koczwara@lrz.uni-muenchen.de 
lymph nodes [3]. Studies in nonobese diabetic (NOD) mice show that diabetes can be delayed by dietary modifications that include hydrolyzed cow's milk [4-6] or deprivation of wheat [7-9]. These effects are most prominent after weaning [8], suggesting that very early life events such as the introduction of new food components are relevant in modifying type 1 diabetes risk.

Food introduction into the human diet varies between countries and ethnicity, but general principles are exclusively breast milk or formula feeding during the first 4-6 months of life, with solid foods such as cereal, vegetables and fruit being introduced between 17 and 26 weeks of age. Whole cow's milk is not recommended until after 12 months of age, and gluten should be gradually introduced between 4 and 7 months of age [10]. Here we tested the effects of introducing single foods encountered in the early infant diet on diabetes development in the NOD mouse.

\section{Research Design and Methods}

\section{Animals}

NOD mice were originally obtained from Taconics (Germantown, N.Y., USA) and the colony established at the Diabetes Research Institute Munich. The animals were kept under specific pathogen-free conditions and all experiments were performed using the principles of animal care (NIH publication No. 85-23, revised 1996) and following the national laws on Protection of Animals.

\section{Diets}

Three sets of diets were prepared to (1) establish a low-diabetogenic diet, (2) investigate the effects of wheat proteins and (3) investigate the diabetogenic effects of foods introduced into infant diets.

To obtain a simple low-diabetogenic basal diet, 3 diets were developed with the purpose to assemble standardized, isocaloric and isonitrogenic diets in cooperation with the Institute of Animal Nutrition and Nutritional Physiology, University Giessen (table 1). All 3 diets had a protein content of $15.5-16 \%$ and extracted soybean meal (Raiffeisen, Langgöns, Germany) and soybean oil (Heidenreich, Mannheim, Germany) as the common protein source. The other 3 experimental protein sources were shredded summer wheat (whole grain; regional provenance, Hesse, Germany) and whole bovine casein (Meggle, Wasserburg, Germany) in diet A, whole bovine casein (Meggle) in diet B and poultry meal (Josera, Kleinheubach, Germany) in diet C. Effects of soluble dietary fiber on lipid metabolism and an enhancement of glucose homeostasis and insulin action have been described [11]. Varying amounts of cellulose were added to diets in order to have approximately $5 \%$ fiber content (table 1). The ingredients of the diets were otherwise identical; vitamins (DSM, Sittard, Netherlands) and minerals (Sigma-Aldrich, Deisenhofen, Germany) were administered in amounts recommended by the National Research Council [12]. The reference diet used was Altromin
1324 (Altromin GmbH \& Co. KG, Lage, Germany; termed diet D) which contains various other protein sources (wheat, wheat bran, wheat middling, soy, barley, corn, fish meal, whey and lupine; table 1).

To further analyze the influence of wheat protein fractions and wheat protein amounts on diabetes development, 4 additional modifications of diet C (soy and poultry protein) were prepared by including 5\% purified wheat gluten (Sigma-Aldrich), or 5, 10 or $30 \%$ of whole wheat, respectively. In addition, the albumin/ globulin fraction of wheat was extracted from wheat flour type 550 [13-15], analyzed for purity by gel electrophoresis and for protein content by BCA Protein Assay Kit (Thermo Fisher Scientific Inc., Rockford, Ill., USA; data not shown), and included as a diet additive in some mice by adding it to the drinking water in amounts corresponding to a $30 \%$ wheat diet.

To determine the influence of food components that are commonly introduced into German infant's diet very early in life, further variations of diet $\mathrm{C}$ (soy and poultry protein) were developed by adding $5 \%$ of whole dried and grounded apple, carrot, potato or corn.

All diets were pelleted and stored in aliquots at $-20^{\circ} \mathrm{C}$. Diet pellets were changed twice weekly and mice had access to diet pellets and water ad libitum.

\section{Dietary Intervention Protocols}

Two protocols were followed (fig. 1). In protocol A, 5 breeding pairs were fed diet B (soy protein and casein) continuously during mating, gestation and nursing (fig. 1a). At 3 weeks of age, the female offspring were litter match randomized into 3 experimental groups and fed the following dietary protocols: group 1 continued with diet B (soy protein and casein), group 2 was fed diet A (soy protein, casein and whole wheat protein) and group 3 received diet $\mathrm{D}$ (Altromin 1324). For diet C, 3 breeding pairs were fed diet $\mathrm{C}$ (soy and poultry protein) continuously during mating, gestation and nursing. At 3 weeks of age, female offspring from those breeding pairs were assigned to 1 group, continuing on $\operatorname{diet} \mathrm{C}$ (soy and poultry protein; fig. 1a).

Protocol B is divided into 2 experimental parts to investigate the diabetogenic effects of wheat proteins and early infant dietary components. For both subgroups, 1 control group, derived from the breeding pairs of protocol $\mathrm{B} 1$ and remaining on basal diet $\mathrm{C}$ without supplements, was used. In protocol B1, 8 breeding pairs were fed diet $\mathrm{C}$ (soy and poultry protein) continuously during mating, gestation and nursing (fig. 1b). At 3 weeks of age the female offspring were litter match randomized into 5 experimental groups and fed the following dietary protocols: group 1 was fed diet $C$ supplemented with $5 \%$ purified wheat gluten, group 2 received diet C supplemented with $30 \%$ whole wheat, group 3 was fed diet $\mathrm{C}$ supplemented with $10 \%$ whole wheat and group 4 received diet $\mathrm{C}$ supplemented with $5 \%$ whole wheat. Group 5 was fed diet $\mathrm{C}$ and received the wheat albumin and globulin fraction via their drinking water. In protocol B2, 6 breeding pairs were fed diet $C$ (soy and poultry protein) continuously during mating, gestation and nursing (fig. 1b). At 3 weeks of age the female offspring was litter matched randomized into 4 experimental groups and fed the following dietary protocols: group 1 was fed diet $C$ supplemented with $5 \%$ whole potato, group 2 received diet $C$ supplemented with $5 \%$ whole corn, group 3 was fed diet $\mathrm{C}$ supplemented with $5 \%$ whole carrot and group 4 received diet $\mathrm{C}$ supplemented with $5 \%$ whole apple. 
Table 1. Composition of the 3 experimental and the reference diets

\begin{tabular}{|c|c|c|c|c|}
\hline & $\begin{array}{l}\text { Diet A } \\
\text { (Soybean meal, } \\
\text { casein, wheat) }\end{array}$ & $\begin{array}{l}\text { Diet B } \\
\text { (Soybean meal, } \\
\text { casein) }\end{array}$ & $\begin{array}{l}\text { Diet C } \\
\text { (Soybean meal, } \\
\text { poultry meal) }\end{array}$ & $\begin{array}{l}\text { Diet D } \\
\text { (Altromin 1324) }\end{array}$ \\
\hline \multicolumn{5}{|l|}{ Dietary ingredients, $\mathrm{g} / \mathrm{kg}$ diet } \\
\hline Shredded summer wheat, whole grain ${ }^{\mathrm{a}}$ & 300 & & $* *$ & $300-600$ \\
\hline Casein $^{\mathrm{b}}$ & 125 & 125 & & - \\
\hline Poultry meal ${ }^{\mathrm{c}}$ & & & 150 & + \\
\hline Extracted soybean meal ${ }^{\mathrm{d}}$ & 50 & 100 & 100 & + \\
\hline Saccharose $\mathrm{e}^{\mathrm{e}}$ & 60 & 60 & 60 & \\
\hline Cellulose $^{\mathrm{f}}$ & $35^{*}$ & 50 & $50^{* *}$ & \\
\hline Soybean oilg & 40 & 40 & 40 & \\
\hline D/L-methionine ${ }^{h}$ & 3 & 3 & 3 & \\
\hline Cholin chloride $^{\mathrm{i}}$ & 2 & 2 & 2 & \\
\hline Macro- and micromineral premix ${ }^{j}$ & 35 & 35 & 35 & recommended amount \\
\hline Vitamin premix $\mathrm{x}^{\mathrm{k}}$ & 10 & 10 & 10 & recommended amount \\
\hline Other dietary ingredients & 0 & 0 & $* *$ & $* * *$ \\
\hline Maize starch ad 1,000 $\mathrm{g}^{\mathrm{l}}$ & 342 & 575 & 550 & \\
\hline Total & 1,000 & 1,000 & 1,000 & 1,000 \\
\hline \multicolumn{5}{|l|}{ Energy and nutrient contents } \\
\hline Metabolizable energy, $\mathrm{kcal} / \mathrm{kg}$ & 2,905 & 2,988 & 3,030 & 2,500 \\
\hline Crude protein, $\mathrm{g} / \mathrm{kg}$ & 161 & 156 & 155 & 190 \\
\hline Crude fat, $\mathrm{g} / \mathrm{kg}$ & 43 & 42 & 45 & 40 \\
\hline Carbohydrates, g/kg & 693 & 673 & 648 & $* * * *$ \\
\hline Dry matter, g/kg & 892 & 915 & 903 & approx. 900 \\
\hline
\end{tabular}

The dietary ingredients are listed as grams per kilogram diet.

${ }^{a}$ Regional provenance, Hesse, Germany.

${ }^{\mathrm{b}}$ Meggle, Wasserburg, Germany.

${ }^{c}$ Josera, Kleinheubach, Germany.

d Raiffeisen, Langgöns, Germany.

e Südzucker, Mannheim, Germany.

${ }^{\mathrm{f}}$ Rettenmaier, Holzmühle, Germany.

g Heidenreich, Mannheim, Germany.

h Degussa, Hanau, Germany.

i DSM, Sittard, Netherlands.

j All salts used for the macro- and microelement premix were obtained from Sigma-Aldrich, St. Louis, Mo., USA. The macroand microelement premix was blended in maize starch to obtain final dietary concentrations as recommended by the NRC (1995) and contained the following compounds: $12.5 \mathrm{~g} \mathrm{CaCO}_{3}=5.0 \mathrm{~g} \mathrm{Ca}$, $15.0 \mathrm{~g} \mathrm{KH}_{2} \mathrm{PO}_{4}=2.65 \mathrm{~g} \mathrm{P} 7.5 \mathrm{~g} \mathrm{Na}_{2} \mathrm{HPO}_{4}=1.63 \mathrm{~g} \mathrm{P}, 5.0 \mathrm{~g} \mathrm{MgSO}_{4}$ $\times 7 \mathrm{H}_{2} \mathrm{O}=500 \mathrm{mg} \mathrm{Mg}, 1.0 \mathrm{~g} \mathrm{NaCl}=0.60 \mathrm{~g} \mathrm{Cl}, 24 \mathrm{mg} \mathrm{CuSO}{ }_{4} \times$ $5 \mathrm{H}_{2} \mathrm{O}=6 \mathrm{mg} \mathrm{Cu}, 175 \mathrm{mg} \mathrm{FeSO}{ }_{4} \times 7 \mathrm{H}_{2} \mathrm{O}=35 \mathrm{mg} \mathrm{Fe}, 50 \mathrm{mg}$ $\mathrm{ZnSO}_{4} \times 7 \mathrm{H}_{2} \mathrm{O}=10 \mathrm{mg} \mathrm{Zn,} 28 \mathrm{mg} \mathrm{MnSO}_{4} \times \mathrm{H}_{2} \mathrm{O}=10 \mathrm{mg} \mathrm{Mn}$, $7.5 \mathrm{mg} \mathrm{CrCl}{ }_{3}=2.5 \mathrm{mg} \mathrm{Cr}, 2.2 \mathrm{mg} \mathrm{NaF}=1 \mathrm{mg} \mathrm{F}, 0.2 \mathrm{mg} \mathrm{KJ}=0.15$ $\mathrm{mg} \mathrm{J}, 0.37 \mathrm{mg} \mathrm{Na}_{2} \mathrm{SeO}_{4}=0.15 \mathrm{mg} \mathrm{Se}, 1.2 \mathrm{mg} \mathrm{CoSO} 4 \times 7 \mathrm{H}_{2} \mathrm{O}=$ $0.25 \mathrm{mg} \mathrm{Mo}, 0.5 \mathrm{mg} \mathrm{Na}_{2} \mathrm{MoO}_{4} \times 2 \mathrm{H}_{2} \mathrm{O}=0.2 \mathrm{mg} \mathrm{Mo}$.
${ }^{\mathrm{k}}$ All vitamins used for the vitamin premix were obtained from DSM. The vitamin premix was blended in maize starch to obtain final dietary concentrations as recommended by the NRC (1995) and contained the following compounds: 15,000 IU vitamin A; $1,500 \mathrm{IU}$ vitamin $\mathrm{D}, 15 \mathrm{IU}$ vitamin $\mathrm{E} ; 1 \mathrm{mg}$ vitamin $\mathrm{K}_{3} ; 5 \mathrm{mg}$ vi$\operatorname{tamin} \mathrm{B}_{1} ; 7$ mg vitamin $\mathrm{B}_{2} ; 6$ mg vitamin $\mathrm{B}_{6} ; 0.02 \mathrm{mg}$ vitamin $\mathrm{B}_{12}$; $0.20 \mathrm{mg}$ biotin; $15 \mathrm{mg}$ niacin; $16 \mathrm{mg}$ pantothenic acid.

${ }^{1}$ Roquette, Lestrem, France.

* In diet A, the cellulose content was reduced, considering the fiber content of shredded wheat.

${ }^{* *}$ In the variations of diet $\mathrm{C}$ containing $5 \%$ wheat, $10 \%$ wheat or $30 \%$ wheat, the cellulose content was successively reduced to 45,40 and $35 \mathrm{~g} / \mathrm{kg}$, respectively. In the variations of diet C containing $5 \%$ potato, corn, carrot or apple, the cellulose content was reduced to $40 \mathrm{~g} / \mathrm{kg}$ considering the natural fiber content of these products.

*** Varying amounts of soybean meal, barley, corn, fish meal, whey and lupin meal.

**** The total carbohydrate content of the Altromin diet 1324 is dependent on the complexity of the natural diet ingredients and is therefore variable. From the batches of Altromin diet 1324 used for this study the total carbohydrate content is not available. 
Fig. 1. Dietary intervention protocols in breeding pairs and their female offspring. To establish a low-diabetogenic diet (a), breeding pairs were fed either diet B or diet $\mathrm{C}$ and groups of randomized female offspring received diets with different protein sources. To investigate the effects of individual food components on diabetes development, 2 food groups were analyzed (b). All breeding pairs were fed diet $\mathrm{C}$ without supplements. In dietary intervention protocol B1, groups of female offspring received diet $\mathrm{C}$ supplemented with varying amounts of whole wheat or wheat protein fractions, to analyze the effects of wheat proteins. In dietary intervention protocol B2, groups of female offspring received diet $C$ supplemented with selected single foods, to analyze effects of foods introduced into early infant diet. For both dietary intervention protocols, 1 group of mice fed with diet $\mathrm{C}$ without supplements was used as control group.

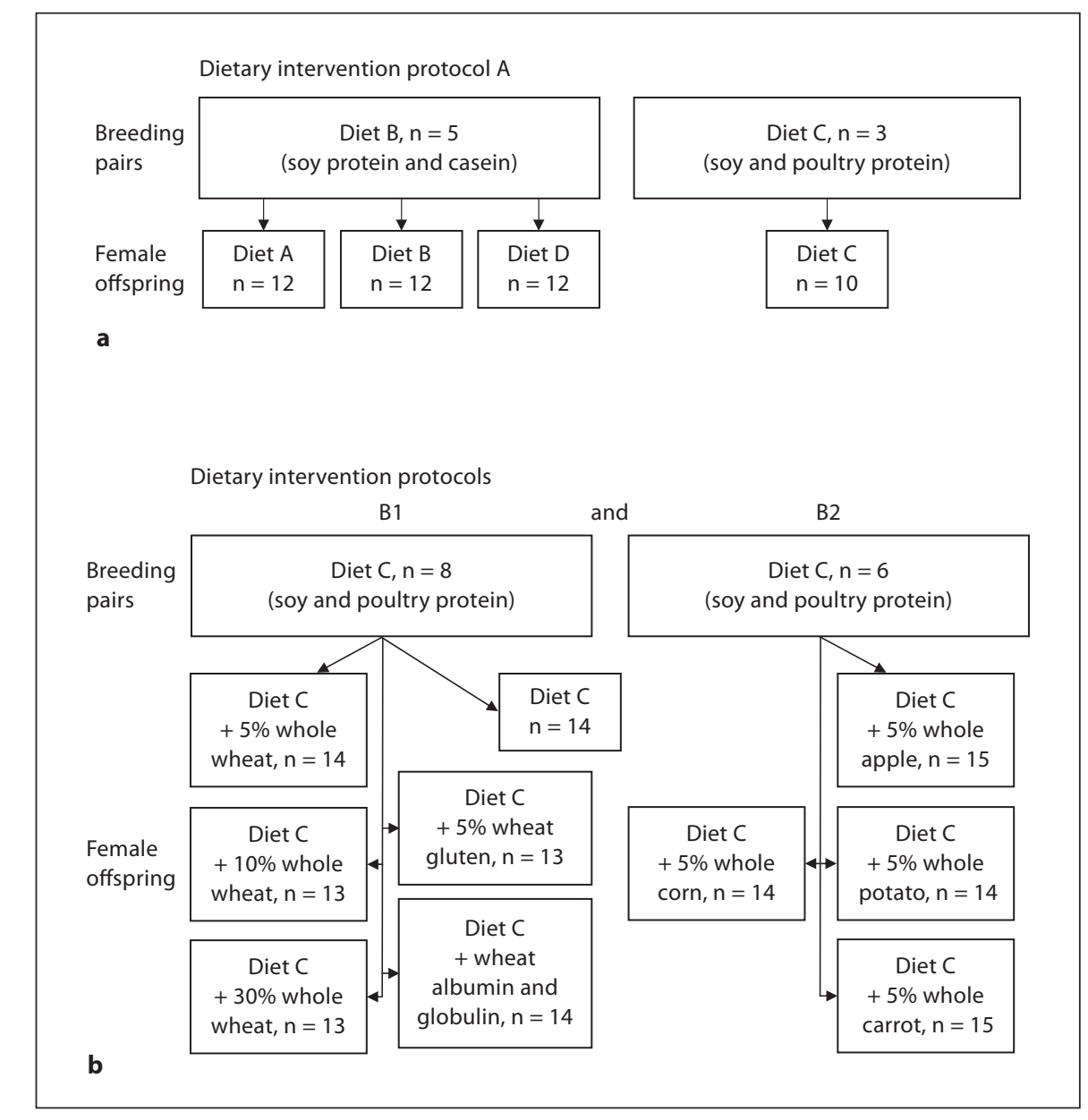

\section{Follow-Up of Mice}

All female offspring included into the experimental groups were followed until diabetes onset or the age of 36 weeks. The daily food intake was determined by measurement of food consumption between 3 and 17 weeks of age in each intervention group. The body weight gain of all treated female offspring was determined by weight measurement at 3 and 10 weeks of age. Urine glucose levels were measured twice per week using urine glucose sticks (Glucetur Test; Boehringer Mannheim, Mannheim, Germany) beginning at 10 weeks of age. Mice were considered to be diabetic after 2 consecutive urine glucose values $>5.5 \mathrm{mmol} / \mathrm{l}$ and blood glucose levels above $13.9 \mathrm{mmol} / \mathrm{l}$ (Glucometer Elite; Bayer Diagnostics GmbH, Munich, Germany). For blood glucose measurements blood was drawn from the tail vein. At 10 weeks of age blood was taken from the eye vein (plexus venorum retroorbitalis) for the measurement of insulin antibodies.

\section{Insulin Autoantibodies}

Antibodies to insulin were detected using a radiobinding assay as previously described [16]. The upper limit of normal was determined from the 99th centile values obtained in sera from $\mathrm{BALB} / \mathrm{c}$ and $\mathrm{C} 57 \mathrm{BL} / 6$ female mice and corresponded to $\geq 1.3$ local units. The assay is represented as laboratory $B$ in the animal models of diabetes workshop [17]. All measurements were performed on coded samples that were operator blinded.

\section{Statistical Analysis}

Diabetes-free survivals in the experimental groups were assessed by Kaplan-Meier analysis and comparisons between groups were calculated using the log-rank test. The Mann-Whitney U test was used to compare insulin antibody levels and the least significant difference test was used to compare the average daily energy intake between treatment groups. Two-tailed $p<0.05$ were considered significant. For all statistical methods, the Statistical Package for Social Sciences (SPSS 16.0; SPSS Inc., Chicago, Ill., USA) was used.

\section{Results}

\section{Daily Nutrient Intake and Weight Gain}

The individual dietary modifications fed to the breeding pairs during mating, gestation and nursing resulted in very similar body weights of the female offspring di- 
Table 2. The average daily food and energy intake of female NOD mice at 10 weeks of age within the individual dietary intervention groups

\begin{tabular}{llll}
\hline \multirow{2}{*}{ Diet } & \multirow{2}{*}{$\begin{array}{l}\text { Mice/ } \\
\text { group }\end{array}$} & At 10 weeks of age \\
\cline { 3 - 4 } & & $\begin{array}{l}\text { Food intake, } \\
\text { g/mouse/day }\end{array}$ & $\begin{array}{l}\text { Energy intake, } \\
\text { kcal/mouse/day }\end{array}$ \\
\hline Diet A (soy, wheat, casein) & 12 & $2.36 \pm 0.36$ & $7.09 \pm 1.08^{\mathrm{a}, \mathrm{b}}$ \\
Diet B (soy, casein) & 12 & $2.29 \pm 0.35$ & $6.87 \pm 1.05^{\mathrm{a}, \mathrm{b}}$ \\
Diet C (soy, poultry) & 10 & $2.49 \pm 0.09$ & $7.66 \pm 0.15^{\mathrm{a}}$ \\
Diet D (Altromin 1324) & 12 & $3.57 \pm 0.35$ & $8.92 \pm 0.87^{\mathrm{c}}$ \\
Diet C (soy, poultry) & 14 & $2.64 \pm 0.06$ & $8.01 \pm 0.19^{\mathrm{a}-\mathrm{c}}$ \\
Diet C + 5\% whole wheat & 14 & $2.70 \pm 0.08$ & $8.12 \pm 0.25^{\mathrm{b}, \mathrm{c}}$ \\
Diet C + 10\% whole wheat & 13 & $2.67 \pm 0.04$ & $8.05 \pm 0.13^{\mathrm{b}, \mathrm{c}}$ \\
Diet C + 30\% whole wheat & 13 & $2.67 \pm 0.10$ & $7.87 \pm 0.29^{\mathrm{a}, \mathrm{b}}$ \\
Diet C + 5\% wheat gluten & 13 & $2.54 \pm 0.08$ & $7.65 \pm 0.25^{\mathrm{a}, \mathrm{b}}$ \\
Diet C + wheat albumin & & & \\
and globulin & 14 & $2.65 \pm 0.06$ & $8.06 \pm 0.20^{\mathrm{a}-\mathrm{c}}$ \\
Diet C + 5\% whole apple & 15 & $2.72 \pm 0.07$ & $8.17 \pm 0.21^{\mathrm{b}, \mathrm{c}}$ \\
Diet C + 5\% whole potato & 14 & $2.59 \pm 0.07$ & $7.87 \pm 0.20^{\mathrm{a}-\mathrm{c}}$ \\
Diet C + 5\% whole corn & 14 & $2.65 \pm 0.07$ & $8.08 \pm 0.22^{\mathrm{a}-\mathrm{c}}$ \\
Diet C + 5\% whole carrot & 15 & $2.71 \pm 0.14$ & $7.99 \pm 0.42^{\mathrm{a}-\mathrm{c}}$ \\
\hline
\end{tabular}

Data are presented as means \pm SD. Different superscripts indicate significant differences $(p<0.05)$ between treatment groups (least significant difference test, SPSS 16.0).

Table 3. Final diabetes incidences of the individual dietary intervention groups after 36 weeks of observation

\begin{tabular}{lll}
\hline Diet & $\begin{array}{l}\text { Mice/ } \\
\text { group }\end{array}$ & $\begin{array}{l}\text { Diabetes } \\
\text { incidence } \\
\text { at 36 weeks, \% }\end{array}$ \\
\hline Diet A (soy, wheat, casein) & 12 & 83 \\
Diet B (soy, casein) & 12 & 92 \\
Diet C (soy, poultry) & 10 & 85 \\
Diet D (Altromin 1324) & 12 & 83 \\
Diet C (soy, poultry) & 14 & 79 \\
Diet C + 5\% whole wheat & 14 & 79 \\
Diet C + 10\% whole wheat & 13 & 77 \\
Diet C + 30\% whole wheat & 13 & 38 \\
Diet C + 5\% wheat gluten & 13 & 62 \\
Diet C + wheat albumin and globulin & 14 & 57 \\
Diet C + 5\% whole apple & 15 & 67 \\
Diet C + 5\% whole potato & 14 & 64 \\
Diet C + 5\% whole corn & 14 & 71 \\
Diet C + 5\% whole carrot & 15 & 80 \\
\hline
\end{tabular}

rectly after weaning. The average weight of mice in the groups was 7.1-8.5 g per mouse at age 3 weeks and 19.522.9 g per mouse at age 10 weeks. The experimental dietary groups did not vary in their average daily food intake (2.5-2.7 g per mouse) and energy intake (7.7-8.2 kcal per mouse; data at 10 weeks of age shown in table 2). Although the reference diet $\mathrm{D}$ used in dietary intervention protocol A had a lower content of metabolizable energy $(2,500 \mathrm{kcal} / \mathrm{kg}$; table 1$)$, the average daily food $(3.5 \mathrm{~g}$ per mouse) and energy intake ( $8.8 \mathrm{kcal}$ per mouse; data at 10 weeks of age shown in table 2) are increased.

\section{Identification of a Low-Diabetogenic Diet}

Mice were bred, weaned and distributed to the different intervention groups according to dietary intervention protocol A (fig. 1a). For all 3 diets, around $80 \%$ of female NOD mice developed diabetes by age 36 weeks (table 3 ). There were, however, significant differences in the rate of diabetes development (fig. 2a). Diabetes rate was fastest in mice that received wheat protein containing diets $\mathrm{A}$ (soy protein, whole wheat protein and casein; 75\% diabetes by age 25 weeks) and D (Altromin 1324; 67\% by age 25 weeks). In comparison, mice that received the wheatand casein-free diet C (soy and poultry protein) had a significantly delayed onset of diabetes by 25 weeks of age ( $38 \%$ diabetes; $p=0.046$ vs. diet A). Mice that received the wheat-free but casein-containing diet B (soy protein and casein) had an intermediate rate of diabetes development ( $50 \%$ at 25 weeks of age). Diet $\mathrm{C}$ was therefore selected as the basal low-diabetogenic diet for the subsequent experiments.

\section{Diabetogenic Effects of Wheat Additives}

Mice were bred, weaned and distributed to the different experimental groups according to protocol B1 (fig. 1b). Diabetes development in mice fed the basal diet C (36\% by age 25 weeks) was very similar to that observed in mice from protocol A ( $38 \%$ by age 25 weeks). An increased rate of diabetes was observed in mice receiving diet $C$ plus $5 \%$ wheat protein (71\% diabetic animals at 25 weeks of age, $\mathrm{p}=0.023$; fig. $2 \mathrm{~b}$ ). However, mice receiving $30 \%$ wheat supplement did not show an accelerated diabetes development (38\% at 25 weeks of age) and mice receiving $10 \%$ wheat supplement had an intermediate diabetes development rate ( $54 \%$ by age 25 weeks). The addition of wheat gluten or wheat albumins and globulins - amounts adjusted to $30 \%$ wheat content - to basal diet C did not increase the diabetes rate ( $31 \%$ by age 25 weeks for the diet C plus $5 \%$ gluten fed mice and $29 \%$ by age 25 weeks for the diet $\mathrm{C}$ plus wheat albumins and globulins fed mice; 

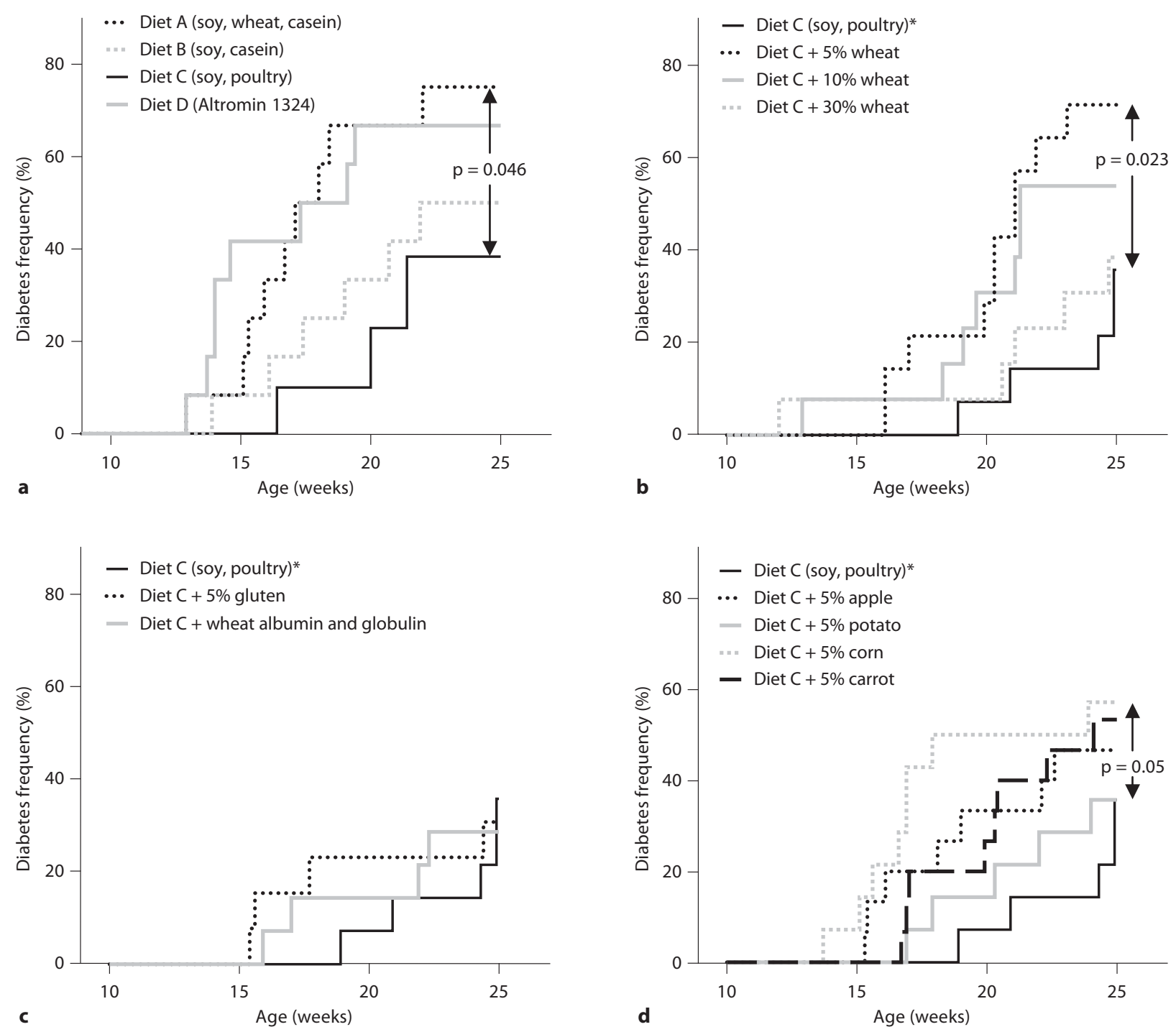

Fig. 2. Cumulative diabetes incidences by life table analyses at 25 weeks of age in female NOD mice treated under intervention protocol A with respect to various protein sources to establish a lowdiabetogenic diet (a), dietary intervention protocol B1 with respect to wheat protein amounts (b) and wheat protein fractions to investigate the effects of wheat proteins (c), and intervention protocol B2 with respect to foods encountered in early infant diet to investigate their diabetogenic effects (d). The same group of mice fed with diet $\mathrm{C}$ without supplements was been used in $\mathbf{b}, \mathbf{c}$ and $\mathbf{d}$, and is indicated with an asterisk. fig. 2c). The increased rate of diabetes observed in mice receiving diet $\mathrm{C}$ plus $5 \%$ wheat protein remained increased until the end of the observation period at 36 weeks of age (79\% diabetic mice) in comparison to mice receiving diet $\mathrm{C}$ plus $30 \%$ wheat protein (38\% diabetic mice; $p=0.031$; table 3 ). No significantly different diabetes rates at 36 weeks of age were detectable for the other treatment groups of intervention protocol B1 (table 3).

\section{Diabetogenic Effects of Early Infant Dietary \\ Components}

Mice were bred, weaned and distributed to the different experimental groups according to protocol B2 (fig. 1b). Diets were supplemented with $5 \%$ of selected foods encountered in infant diet. Compared to the control group that was fed the basal diet $C$, all of these food supplements resulted in slight to moderate acceleration of diabetes de- 


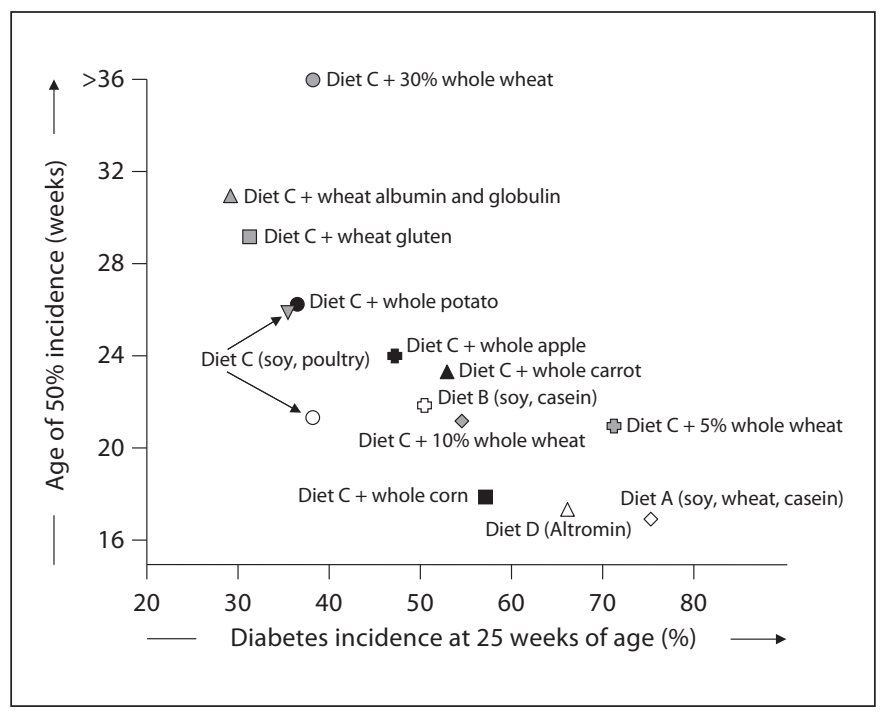

Fig. 3. The effects of the different diets on the rate of diabetes development. Diabetes incidences at 25 weeks of age in female NOD mice (x-axis) are plotted in relation to the age of $50 \%$ diabetes incidence (y-axis) for each individual dietary intervention group. For a direct comparison, the groups of each intervention protocol are shown in one plot. The treatment groups of intervention protocol A with respect to various protein sources to establish a lowdiabetogenic diet are indicated by transparent symbols, of intervention protocol $\mathrm{B} 1$ with respect to wheat and wheat components to investigate the diabetogenic effects of wheat proteins are indicated by shaded symbols, and of intervention protocol B2 with respect to foods encountered in early infant diet to investigate their diabetogenic effects are indicated by filled symbols.

velopment when they were introduced after weaning (fig. $2 \mathrm{~d}$ ). In particular, mice receiving diet $\mathrm{C}$ plus $5 \%$ corn had a significantly earlier onset of diabetes with $50 \%$ of diabetic mice before 18 weeks of age (57\% at age 25 weeks; $\mathrm{p}=0.05$ vs. basal diet C). At the end of the observation period, no significant differences in the diabetes rates were detectable between the treatment groups of intervention protocol B2 (table 3).

Figure 3 summarizes the effects of the different diets on the rate of diabetes development. The most consistent finding was a faster diabetes rate in mice that received diets containing unfractionated cereal proteins (wheat or corn), albeit with exceptions (diet C supplemented with $30 \%$ wheat proteins).

\section{Insulin Autoantibodies}

None of the experimental diets affected the prevalence or titer of insulin autoantibodies at 10 weeks of age in the treated mice (fig. 4).

\section{Discussion}

We have investigated the effects of early dietary food supplements on the rate of diabetes development in the NOD mouse using controlled conditions. The findings show little effects on overall diabetes incidence and mild to moderate increases in diabetes rate when cereal food supplements are added to a basal calorie-controlled diet. The increased rates were not associated with any single food supplement and for wheat appeared to be dose dependent.

The relative strength of this study is that experimental diets and conditions were controlled with respect to diet protein, fat and carbohydrate content as well as energy intake. To achieve this, we relied on noncommercial sources of mouse feed since commercial sources were found to have numerous components and were inconsistent from batch to batch. All diets were prepared in one institute. In order to obtain a low-diabetogenic diet, both casein and wheat sources of protein were eliminated. Elimination of only wheat was only partially effective in reducing diabetes rate. The findings with respect to wheat and casein as potentially diabetogenic in the NOD mouse have been previously reported [4-9, 18-21]. The relatively slow diabetes rate (around $37 \%$ by age 25 weeks) observed when the source of protein was limited to soy and poultry was reproducible in 2 trials in our experiments, suggesting that the finding is bona fide. Thus, we recommend such a diet for future studies in which conditions that increase diabetogenicity in the NOD mouse are investigated.

Using the low-diabetogenicity diet, we were able to investigate the effects of single food source supplements on diabetes development. The results were not entirely confirmatory of previous findings. We and others had previously shown a marked decrease in diabetes incidence when wheat and barley were removed from the diet of NOD mice $[8,9,18]$. We could not entirely reproduce this effect in the current series of experiments under controlled dietary conditions. Certainly the absence of wheat contributed to low diabetogenicity, but adding wheat proteins as a supplement to a low-diabetogenic, wheat-free diet increased diabetes rate only when low concentrations (5\% weight/weight) were used and not at all when $30 \%$ of the diet ingredients were wheat derived. Since previous effects were observed by removal of wheat from complex diets such as Altromin 1324 which contains 30\% wheat source (and was shown to be a high-diabetogenic diet again in the current series of experiments), it is likely that diabetogenic effects of wheat are complex and vary de- 
Fig. 4. Insulin autoantibody prevalence and titer at 10 weeks of age in female NOD mice treated under dietary intervention protocol A with respect to various protein sources to establish a low-diabetogenic diet (a), dietary intervention protocol B1 with respect to wheat and wheat components (b), and dietary intervention protocol B2 with respect to foods encountered in early infant diet (c). The same group of mice fed with diet $\mathrm{C}$ without supplements has been used in $\mathbf{b}$ and $\mathbf{c}$, and is indicated with an asterisk. The dotted lines indicate the cutoff for positivity. The horizontal lines indicate the mean insulin autoantibody titer per treatment group.

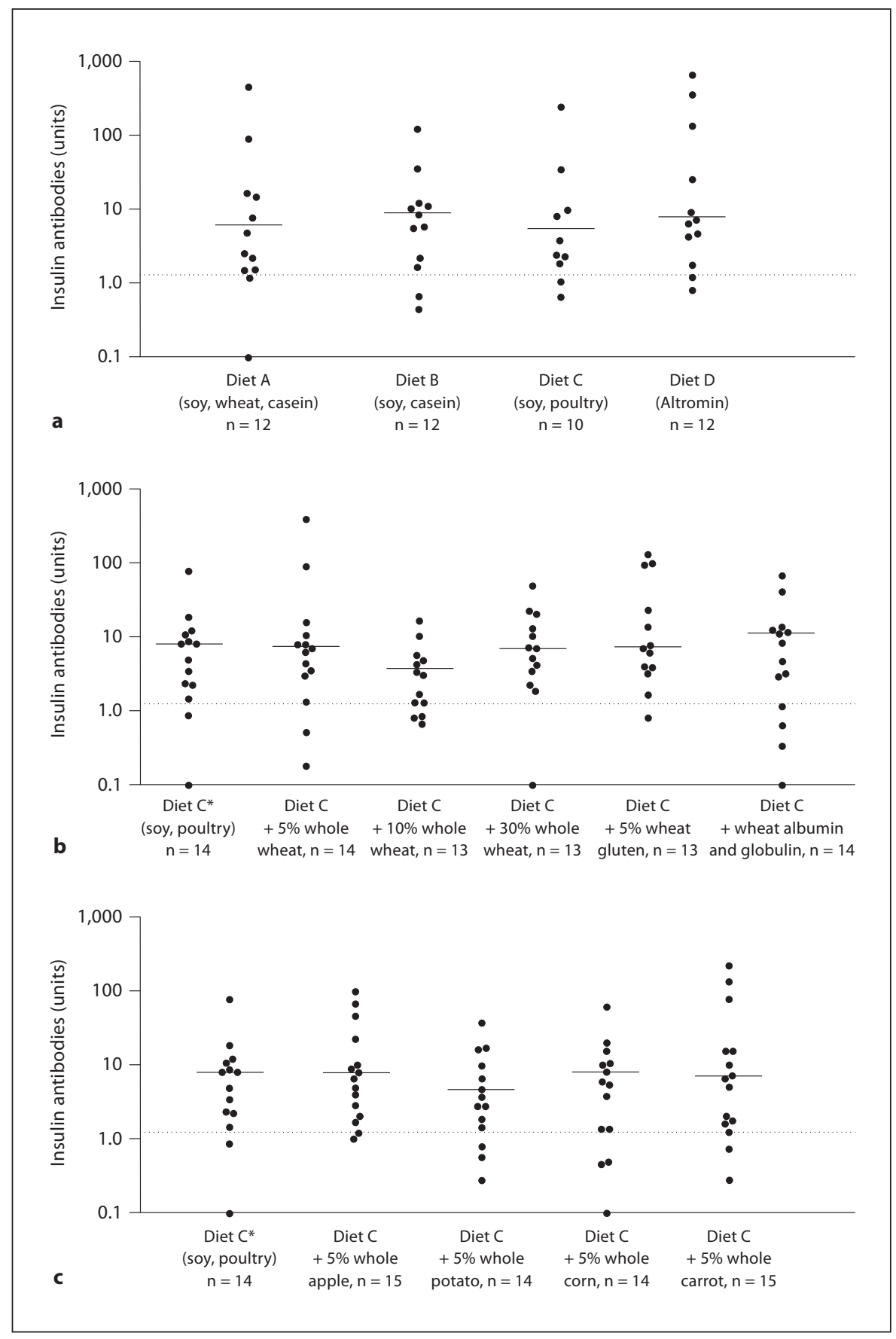

pending upon other components of the diet. It should also be noted that the addition of any single wheat component at a concentration corresponding to $30 \%$ whole wheat did not increase diabetes rate. Finally, a dose-dependent effect whereby only low concentrations are diabetogenic could be explained by tolerogenic effects of high antigen concentration and the possibility that wheat also has components [22] that have antidiabetic properties. These include unsaturated fatty acids and vitamin $\mathrm{E}$, which have been suggested to delay diabetes onset [23], as well as large amounts of phytic acid (up to $1,100 \mathrm{mg} /$ $100 \mathrm{~g}$ in wheat). Studies in rodent models as well as in humans indicate that phytic acid leads to a clear reduction of postprandial blood glucose levels [24-26]. Therefore, a 
decreased requirement for postprandial insulin secretion might preserve the pancreatic $\beta$ cells which could delay the diabetes onset in prediabetic NOD mice.

The addition of foods other than wheat was variable in its effects on diabetes development, but generally increased the rate without affecting overall incidence. The strongest effect was observed when $5 \%$ corn was added. Together with the finding that $5 \%$ wheat was also diabetogenic, it is tempting to conclude that cereals are generally diabetogenic at certain concentrations. The dose dependency of corn and other cereals requires further investigation. The mechanism of the effects of cereals is not clear. Sequence homologies have been described for the wheat storage protein Glbl and tight junction proteins which are involved into the permeability control of intestinal epithelium [27]. Of interest, similar sequence homologies are present for Glb1 protein from corn. Little or no effect on diabetes development was observed when potato, apple and carrot were added to the low-diabetogenicity diet. The absence of an effect on diabetes when dried whole unpeeled potato was added to the diet is inconsistent with a former study describing diabetogenicity of bacterial toxins on the potato peel [28]. Finally, none of the diets affected the development of insulin autoanti- bodies. In previous NOD studies, we have seen a relationship of insulin autoantibodies with diabetes incidence also in relation to wheat exposure [8]. For the current study, the differences in diabetes development at 25 weeks of age may not be sufficiently marked to see an effect at the level of insulin autoantibodies with the number of mice used.

In conclusion, diabetes development in the NOD mouse is influenced by dietary modifications. Using single foods as supplements to a low-diabetogenic casein and wheat-free diet, diabetogenic effects were observed for cereals, but were relatively mild compared to previous findings. In addition, there was a suggestion that the dose of the cereal supplement could be important for diabetogenicity, with greatest effects seen at low cereal dose.

\section{Acknowledgements}

This study forms part of the dissertation of D.B.M. K.K. was supported by the NIH/DFG Research Career Transition Award Program (KO 3418/1-1). The authors thank Annette Knopff, Evi Wagner, Marco Jaeger, Silke Heess, Stephanie Krause, Carola Bartenschlager and Youlia Kostova for excellent technical support.

\section{References}

1 Knip M, Veijola R, Virtanen SM, Hyöty H, Vaarala O, Akerblom HK: Environmental triggers and determinants of type 1 diabetes. Diabetes 2005;54(suppl 2):S125-S136.

$\checkmark 2$ Lefebvre DE, Powell KL, Strom A, Scott FW: Dietary proteins as environmental modifiers of type 1 diabetes mellitus. Annu Rev Nutr 2006;26:175-202.

3 Turley SJ, Lee JW, Dutton-Swain N, Mathis D, Benoist C: Endocrine self and gut non-self intersect in the pancreatic lymph nodes. Proc Natl Acad Sci USA 2005;102:1772917733.

4 Elliott RB, Reddy SN, Bibby NJ, Kida K: Dietary prevention of diabetes in the non-obese diabetic mouse. Diabetologia 1988;31:6264.

$\checkmark 5$ Coleman DL, Kuzava JE, Leiter EH: Effect of diet on incidence of diabetes in nonobese diabetic mice. Diabetes 1990;39:432-436.

-6 Karges W, Hammond-McKibben D, Cheung RK, Visconti M, Shibuya N, Kemp D, Dosch HM: Immunological aspects of nutritional diabetes prevention in NOD mice: a pilot study for the cow's milk-based IDDM prevention trial. Diabetes 1997;46:557-564.
7 Funda DP, Kaas A, Bock T, TlaskalovaHogenova H, Buschard K: Gluten-free diet prevents diabetes in NOD mice. Diabetes Metab Res Rev 1999;15:323-327.

-8 Schmid S, Koczwara K, Schwinghammer S, Lampasona V, Ziegler AG, Bonifacio E: Delayed exposure to wheat and barley proteins reduces diabetes incidence in non-obese diabetic mice. Clin Immunol 2004;111:108118.

-9 Maurano F, Mazzarella G, Luongo D, Stefanile R, D’Arienzo R, Rossi M, Auricchio S, Troncone R: Small intestinal enteropathy in nonobese diabetic mice fed a diet containing wheat. Diabetologia 2005;48:931-937.

10 Agostoni C, Decsi T, Fewtrell M, Goulet O, Kolacek S, Koletzko B, Michaelsen KF, Moreno L, Puntis J, Rigo J, Shamir R, Szajewska H, Turck D, van Goudoever J, ESPGHAN Committee on Nutrition: Complementary feeding: a commentary by the ESPGHAN Committee on Nutrition. J Pediatr Gastroenterol Nutr 2008;46:99-110.
11 Hannan JM, Ali L, Rokeya B, Khaleque J, Akhter M, Flatt PR, Abdel-Wahab YH: Soluble dietary fibre fraction of Trigonella foenum-graecum (fenugreek) seed improves glucose homeostasis in animal models of type 1 and type 2 diabetes by delaying carbohydrate digestion and absorption, and enhancing insulin action. Br J Nutr 2007;97: 514-521.

12 National Research Council (NRC): Nutrient Requirements of Laboratory Animals, ed 4 (rev). Washington, National Academies Press, 1995.

13 Osborne TB (ed): The Proteins of the Wheat Kernel. Washington, Carnegie Institute Publishers, 1907, vol 84.

14 Mimouni B, Robin JM, Azanza JL, Raymond J: Wheat flour proteins: Isolation and functionality of gliadin and HMW-glutenin enriched fractions. J Sci Food Agric 1998;78: 423-428.

15 Nicolas Y, Martinant JP, Denery-Papini S, Popineau Y: Analysis of wheat storage proteins by exhaustive sequential extraction followed by RP-HPLC and nitrogen determination. J Sci Food Agric 1998;77:96-102. 
-16 Koczwara K, Schenker M, Schmid S, Kredel $\mathrm{K}$, Ziegler AG, Bonifacio E: Characterization of antibody responses to endogenous and exogenous antigen in the nonobese diabetic mouse. Clin Immunol 2003;106:155-162.

- 17 Bonifacio E, Atkinson M, Eisenbarth G, Serreze D, Kay T W, Lee-Chan E, Singh B: International workshop on lessons from animal models for human type 1 diabetes: identification of insulin but not glutamic acid decarboxylase or IA-2 as specific autoantigens of humoral autoimmunity in nonobese diabetic mice. Diabetes 2001;50:2451-2458.

-18 Hoorfar J, Buschard K, Dagnaes-Hansen F: Prophylactic nutritional modification of the incidence of diabetes in autoimmune nonobese diabetic (NOD) mice. Br J Nutr 1993; 69:597-607.
19 Beales PE, Elliott RB, Flohé S, Hill JP, Kolb H, Pozzilli P, Wang GS, Wasmuth H, Scott FW: A multi-centre, blinded international trial of the effect of $\mathrm{A}^{1}$ and $\mathrm{A}^{2} \beta$-casein variants on diabetes incidence in two rodent models of spontaneous type I diabetes. Diabetologia 2002;45:1240-1246.

20 Flohé SB, Wasmuth HE, Kerad JB, Beales PE, Pozzilli P, Elliott RB, Hill JP, Scott FW, Kolb $\mathrm{H}$ : A wheat-based, diabetes-promoting diet induces a Th1-type cytokine bias in the gut of NOD mice. Cytokine 2003;21:149-154.

21 Funda DP, Kaas A, Tlaskalová-Hogenová H, Buschard K: Gluten-free but also gluten-enriched (gluten + ) diet prevent diabetes in NOD mice; the gluten enigma in type 1 diabetes. Diabetes Metab Res Rev 2008;24:5963.

22 Pomeranz Y: Wheat: Chemistry and Technology, ed 3. St. Paul, American Association of Cereal Chemists Monograph Series, 1988.

23 Hyppönen E: Micronutrients and the risk of type 1 diabetes: vitamin D, vitamin E, and nicotinamide. Nutr Rev 2004;62:340-347.
24 Dilworth LL, Omoruyi FO, Simon OR, Morrison EY, Asemota HN: The effect of phytic acid on the levels of blood glucose and some enzymes of carbohydrate and lipid metabolism. West Indian Med J 2005;54:102-106.

25 Lee S, Park H, Chun H, Cho S, Cho S, Lillehoj HS: Dietary phytic acid lowers the blood glucose level in diabetic KK mice. Nutr Res 2006;26:474-479.

26 Panlasigui LN, Thompson LU: Blood glucose lowering effects of brown rice in normal and diabetic subjects..Int J Food Sci Nutr 2006;57:151-158.

27 MacFarlane AJ, Burghardt KM, Kelly J, Simell T, Simell O, Altosaar I, Scott FW: A type 1 diabetes-related protein from wheat (Triticum aestivum). cDNA clone of a wheat storage globulin, Glb1, linked to islet damage. J Biol Chem 2003;278:54-63.

28 Myers MA, Hettiarachchi KD, Ludeman JP, Wilson AJ, Wilson CR, Zimmet PZ: Dietary microbial toxins and type 1 diabetes. Ann NY Acad Sci 2003;1005:418-422. 